\title{
Thrombophilia and retinal vascular occlusion
}

This article was published in the following Dove Press journal:

Clinical Ophthalmology

27 August 2012

Number of times this article has been viewed

\section{Charles J Glueck' \\ Robert K Hutchins ${ }^{2,3}$ \\ Joel Jurantee' \\ Zia Khan' \\ Ping Wang}

'Cholesterol Center, Jewish Hospital of Cincinnati, Cincinnati, OH, USA; ${ }^{2}$ Department of Ophthalmology, University of Cincinnati College of Medicine, Cincinnati, OH, USA; ${ }^{3}$ Cincinnati Eye Institute, Cincinnati, $\mathrm{OH}$, USA
Correspondence: Charles J Glueck Cholesterol Center, UC Health Building, 3200 Burnet Avenue, Cincinnati, $\mathrm{OH} 45229$, USA

$\mathrm{Tel}+\mathrm{I} 513924826$ I

Fax + I 5139248273

Email cjglueck@health-partners.org
Purpose: The purpose of this research was to assess associations of thrombophilia with central retinal vein occlusion (CRVO), central retinal artery occlusion (CRAO), and amaurosis fugax (AF); to evaluate outcomes of normalizing high homocysteine; and to study CRVO, CRAO, and $\mathrm{AF}$ developing in estrogens/estrogen agonists in women subsequently shown to have thrombophilia.

Methods: Measures of thrombophilia-hypofibrinolysis were obtained in 132 CRVO cases, 15 CRAO cases, and 17 AF cases. Cases were compared to 105 healthy control subjects who did not differ by race or sex and were free of any ophthalmologic disorders. All cardiovascular disease (CVD) risk factors were compared to healthy general populations.

Main outcome measures: The main outcome measure of this study was thrombophilia. Results: CRVO cases were more likely than controls to have high homocysteine (odds ratio [OR] 8.64, 95\% confidence intervals [CI]: 1.96-38), high anticardiolipin immunoglobulin M (IgM; OR 6.26, 95\% CI: 1.4-28.2), and high Factor VIII (OR 2.47, 95\% CI: 1.31-7.9). CRAO-AF cases were more likely than controls to have high homocysteine (OR 14, 95\% CI: 2.7-71.6) or the lupus anticoagulant (OR 4.1, 95\% CI: 1.3-13.2). In four of 77 women with CRVO (two found to have high homocysteine, two with inherited high Factor XI), CRVO occurred after starting estrogen-progestins, estrogen-testosterone, or estrogen agonists. In one of eight women with CRAO found to have high anticardiolipin antibody IgG, CRAO occurred after starting conjugated estrogens, and AF occurred after starting conjugated estrogens in one of eleven women with AF (inherited protein S deficiency). Therapy for medians of 21 months (CRVO) and 6 months (CRAO-AF) was $5 \mathrm{mg}$ folic acid, $100 \mathrm{mg} \mathrm{B} 6$, and $2000 \mathrm{mcg} / \mathrm{day}$ B12 normalized homocysteine in 13 of $16(81 \%)$ CRVO cases and all five CRAO-AF cases with pretreatment hyperhomocysteinemia. The CRVO cases had an excess of hypertension; CRAO-AF cases had an excess of type 2 diabetes and hypertension.

Conclusion: Treatable thrombophilia, hyperhomocysteinemia in particular, is more common in RVO cases than in normal controls. RVO occurs after estrogens or estrogen agonists were administered in women subsequently shown to have thrombophilia.

Keywords: central retinal vein occlusion, central retinal artery occlusion, amaurosis fugax, retinal vascular occlusion, thrombophilia, estrogen, estrogen agonist

\section{Introduction}

Retinal vascular occlusion (RVO), which includes central retinal vein occlusion (CRVO), central retinal artery occlusion (CRAO), and amaurosis fugax (AF), can be caused by inherited and acquired thrombophilia, particularly homocysteinemia. ${ }^{1-5}$ Thrombophilia associated with exogenous estrogens, ${ }^{6}$ estrogen progestin oral contraceptives, ${ }^{7}$ clomiphene citrate, ${ }^{8}$ or selective estrogen receptor modulators (SERMS) ${ }^{9}$ 
may promote CRVO, ${ }^{8,10-14} \mathrm{AF},{ }^{9,15-17}$ and CRAO. ${ }^{18-20}$ Most studies associating estrogen-progestin oral contraceptives with CRVO or CRAO are case reports of only one to three cases. ${ }^{18,21-23}$ Most reports of CRVO or CRAO associated with estrogens or estrogen agonists ${ }^{8-14,18-21}$ have not assessed interactions between pharmacologic thrombophilia conferred by estrogens or estrogen agonists and the inherited and acquired thrombophilia ${ }^{15,16,24-35}$ known to be causally associated with RVO.

Our specific aim was to assess associations of inherited and acquired thrombophilia-hypofibrinolysis with CRVO, $\mathrm{CRAO}$, and AF; to evaluate outcomes of normalizing high homocysteine levels; and to study CRVO, CRAO, and AF development after the use of estrogens or estrogen agonists in women subsequently shown to have thrombophilia.

\section{Materials and methods Setting and study design Cases}

The study was carried out following a protocol approved by our Institutional Review Board, and with signed informed consent from both the cases and controls. In consecutive order of their referral by six vitreoretinal specialists (two academic, four community-based) in an outpatient clinical research center, we prospectively studied 164 RVO cases (68 men, 96 women). These 164 cases included 132 with CRVO (55 men, 77 women), 15 with CRAO (seven men, eight women), and 17 with AF (six men, eleven women). There were no known selection biases for referral. We excluded from this study any CRAO-AF cases who had hemodynamically significant ipsilateral carotid-vertebral atherosclerotic lesions by carotid-vertebral Doppler measures, ${ }^{30}$ or who had coronary left-to-right shunts determined by trans-esophageal echo studies.

One or more months after their RVO, serologic coagulation assays were done. No cases had taken warfarin or heparin within 3 months of blood sampling. Most cases with CRVO had bevacizumab intraocular injections. At each case's initial visit, a detailed history and physical examination were carried out, with a focus on cardiovascular events, hypertension, diabetes, cigarette smoking, pulmonary embolus, deep venous thrombosis, reproductive history, estrogen-containing oral contraceptives, hormone replacement therapy, clomiphene citrate, SERMS, and therapy for hypertension, diabetes, and hyperlipidemia. Blood specimens for coagulation measures were obtained from seated cases and controls, as previously described, between 8 am and 10 am the morning after an overnight fast. ${ }^{24,25,29}$
CRVO was diagnosed by the referring vitreoretinal specialists based on the results of characteristic fundus features $^{31,33-35}$ including retinal hemorrhages in all four quadrants of the fundus with a dilated, tortuous retinal venous system.

CRAO was diagnosed by the referring vitreoretinal specialists by the presence of acute painless loss of vision with central, dense visual loss. Funduscopic criteria included a whitened retina with a cherry red macula (the "cherry-red spot"), resulting from the obstruction of blood flow to the retina from the central retinal artery. A continued supply of blood to the choroid from the short ciliary arteries resulted in a bright red coloration at the thinnest part of the retina, the macula. We included only those CRAO cases without ipsilateral carotid atherosclerosis.

AF was diagnosed by transient monocular visual loss with normal funduscopic examination in cases without ipsilateral carotid atherosclerotic plaque and without evidence of temporal arteritis.

Cases with hyperhomocysteinemia at entry were treated with folic acid (5 mg/day), vitamin B6 (100 mg/day), and vitamin B12 (2000 mcg/day), with repeat measures of fasting serum homocysteine every 3-4 months and repeated funduscopic examinations every 3-6 months.

\section{Controls}

For comparison with the cases' polymerase chain reaction (PCR) and serologic measures of thrombophilia-hypofibrinolysis, the 132 CRVO cases and the 32 CRAO-AF cases were compared to 105 healthy controls (45 men, 60 women) that had not sustained RVO and did not differ from the cases by ethnicity or sex. By selection, no male controls were taking testosterone and no female controls were taking estrogen-progestin oral contraceptives, hormone replacement therapy, clomiphene citrate, or SERMS. To assess the contributions of cardiovascular risk factors to CRVO and CRAO-AF, cases' lipid levels were characterized by their percentile distributions within age- and gender-specific lipid distributions from healthy general populations documented in the Lipid Research Clinics Prevalence Study. ${ }^{36}$ Separately, the prevalence of type 2 diabetes, hypertension, and smoking in cases with CRVO and CRAO-AF were compared to US population estimates. ${ }^{37,38}$

\section{PCR assays}

PCR measures of thrombophilia-hypofibrinolysis included G1691A Factor V Leiden, G20210A prothrombin, MTHFR C677T-A1298C, and 4G5G plasminogen activator inhibitor activity. These PCR measures were performed in cases with 
CRVO and CRAO-AF and in healthy controls using previously published methods by laboratory staff blinded to the subjects' status (case, control, and severity). ${ }^{15,24,25,28,29,39-44}$

\section{Serologic measures of thrombophilia}

Serologic measures of thrombophilia included anticardiolipin antibodies (IgG and $\operatorname{IgM}$ ), antigenic protein $\mathrm{C}$, total and free antigenic protein $\mathrm{S}$, antithrombin III, resistance to activated protein C (RAPC), activated partial thromboplastin time, dilute Russell's viper venom time (DRVVT), lupus anticoagulant, factors VIII and XI, and homocysteine. Established, previously published methods were used..$^{39,44-46}$ To be considered abnormal, high anticardiolipin antibodies and the lupus anticoagulant had to be abnormal in a second test done 12 weeks after the first. Testing was not done for anti-beta 2 globulin.

\section{Serologic measures of hypofibrinolysis}

Serologic measures of hypofibrinolysis included lipoprotein a (Lp(a)) and plasminogen-activator inhibitor activity. These measures were performed using established methods. . $^{29,45,46}$

\section{Statistical methods}

All statistical comparisons were done using SAS software (SAS/STAT, Release 9.1; SAS Institution, Cary, NC). The proportions of RVO cases and healthy normal controls having abnormalities in coagulation measures were compared using odds ratios and $95 \%$ confidence intervals, and by $\chi^{2}$ analyses or the Fisher exact test when cell sizes were $<5$. Serum homocysteine levels pre- and on-treatment with folic acid, vitamin B6, and vitamin B12 were compared by paired Wilcoxon tests of difference.

\section{Results}

\section{CRVO, CRAO, and AF in the total cohort}

Of the 132 CRVO cases, 121 were white, six black, and five other; 55 were men and 77 women; the mean \pm standard deviation (SD) age was $57 \pm 14$ years. Of the 32 CRAO-AF cases, 30 were white and two black; 13 were men; the mean \pm SD age was $52 \pm 16$ years. CRVO and CRAO-AF cases did not differ from the 105 healthy controls by ethnicity ( 92 white, six black, seven other; $P=0.54, P=0.43$, respectively) or by sex (44 men, 61 women; $P=0.97, P=0.90)$, but the controls were younger (44.2 \pm 12 years, $P<0.0001, P=0.003$, respectively).

In all of the $132 \mathrm{CRVO}$ and $32 \mathrm{CRAO}-\mathrm{AF}$ cases, CRVO and CRAO-AF were the cases' first thrombotic event. By selection, CRAO-AF cases did not have carotid artery atherosclerosis or right-to-left heart shunts, which might have accounted for their RVO.

\section{Case-control differences in thrombophilia}

CRVO cases were more likely than normal controls to have high homocysteine, high anticardiolipin IgM, and high Factor VIII (Table 1). Low free-antigenic protein $\mathrm{S}$ was

Table I Comparisons of coagulation measures between I 32 patients with CRVO and I 05 healthy, normal controls

\begin{tabular}{|c|c|c|c|c|}
\hline Coagulation measures (normal range) & Abnormal in CRVO & Abnormal in controls & $P$ & OR, $95 \% \mathrm{Cl}$ \\
\hline Homocysteine ( $\leq$ I3.5 $\mu \mathrm{mol} / \mathrm{L})$ & $15 \%(19 / 129)$ & $2 \%(2 / 102)$ & $\chi^{2}=11.2, P=0.0008$ & $8.64,1.96-38.0$ \\
\hline Free antigenic protein S ( $\geq 66 \%$ ) & $9 \%(11 / 120)$ & $2 \%(2 / 92)$ & $\chi^{2}=4.4, P=0.04$ & $4.54,0.98-21.0$ \\
\hline Anticardiolipin antibody IgM (<10 MPL) & $11 \%(14 / 128)$ & $2 \%(2 / 104)$ & $\chi^{2}=7.3, P=0.007$ & $6.26,1.39-28.2$ \\
\hline Factor VIII $(\leq 150 \%)$ & $20 \%(23 / 116)$ & $7 \%(7 / 98)$ & $\chi^{2}=7.1, P=0.008$ & $3.22,1.31-7.86$ \\
\hline Factor V Leiden mutation & $5 \% \mathrm{CT}^{\mathrm{a}}(6 / 130)$ & $2 \%$ CT $(2 / 104)$ & Fisher's $P=0.3$ & \\
\hline Resistance to activated protein C (dated cutpoint) & $8 \%(9 / 112)$ & $5 \%(5 / 92)$ & $\chi^{2}=0.53, P=0.5$ & \\
\hline Prothrombin gene mutation & $3 \%$ CT (4/127) & $3 \%$ CT (3/105) & Fisher's $P=1.0$ & \\
\hline \multirow[t]{2}{*}{ Plasminogen activator inhibitor mutation } & $28 \%$ 4G4G (36/I27) & $26 \% 4 G 4 G(26 / 100)$ & Mantel-Haenszel & \\
\hline & $46 \% 4 G 5 G(59 / 127)$ & $43 \% 4 G 5 G(43 / 100)$ & $\chi^{2}=0.67, P=0.4$ & \\
\hline \multirow[t]{2}{*}{ MTHFR C677T mutation } & $22 \%$ CC $(29 / 130)$ & $31 \%$ CC (31/I0I) & Mantel-Haenszel & \\
\hline & $35 \%$ CT $(45 / 130)$ & I4\% CT (14/I0I) & $\chi^{2}=0.13, P=0.7$ & \\
\hline Antigenic protein $C(\geq 73 \%)$ & $6 \%(7 / 127)$ & $7 \%(6 / 92)$ & $\chi^{2}=0.10, P=0.8$ & \\
\hline Antigenic protein S ( $\geq 63 \%)$ & $2 \%(3 / 125)$ & $4 \%(4 / 92)$ & Fisher's $P=0.5$ & \\
\hline Antithrombin III ( $\geq 80)$ & $7 \%(8 / 121)$ & $2 \%(2 / 92)$ & Fisher's $P=0.2$ & \\
\hline Anticardiolipin antibody IgG $(<22$ GPL) & $10 \%(13 / 127)$ & $7 \%(7 / 104)$ & $\chi^{2}=0.89, P=0.4$ & \\
\hline Plasminogen activator activity ( $\leq 2 \mathrm{I} . \mathrm{I} \mathrm{U} / \mathrm{mL}$ ) & $10 \%(11 / 107)$ & $10 \%(10 / 97)$ & $\chi^{2}=0.0, P=1.0$ & \\
\hline $\mathrm{Lp}(\mathrm{a})(<35 \mathrm{mg} / \mathrm{dL})$ & $20 \%(25 / 123)$ & $20 \%(20 / 102)$ & $\chi^{2}=0.02, P=0.9$ & \\
\hline Resistance to activated protein C (dated cutpoint) & $8 \%(9 / 112)$ & $5 \%(5 / 92)$ & $\chi^{2}=0.53, P=0.5$ & \\
\hline Factor XI $(<150 \%)$ & $4 \%(5 / 1 / 4)$ & $2 \%(2 / 96)$ & Fisher's $P=0.5$ & \\
\hline Lupus anticoagulant & $10 \%(9 / 87)$ & $9 \%(7 / 8 I)$ & $\chi^{2}=0.14, P=0.7$ & \\
\hline
\end{tabular}

Abbreviations: $\mathrm{Cl}$, confidence interval; $\mathrm{C}$, mutant allele; OR, odds ratio; T, wild-type normal allele; Lp(a), lipoprotein a; CRVO, central retinal vein occlusion. 
marginally more common (by Chi squared analysis) in cases than in controls (Table 1). There were no other case-control differences $(P>0.05)$ in any other CRVO case-control comparisons of coagulation measures (Table 1).

CRAO-AF cases were more likely than normal controls to have high homocysteine or the lupus anticoagulant (Table 2). There were no other case-control differences $(P>0.05)$ in any other case-control comparisons of coagulation measures (Table 2).

\section{Normalization of elevated serum homocysteine by folic acid, vitamin B6, and vitamin BI2}

Of the 19 CRVO cases with high pre-treatment homocysteine (Table 1), 16 had had treatment with folic acid-vitamin B6-vitamin B12 with a median follow-up of 21 months (interquartile range 3-60 months). Homocysteine levels fell in every case on treatment, from $19.1 \pm 8.7$ to $9.8 \pm 3.9 \mu \mathrm{mol} / \mathrm{L}, P<0.0001$, and normalized $(\leq 13.5 \mu \mathrm{mol} / \mathrm{L})$ in 13 of 16 cases $(81 \%)$. In these 16 cases, there were no new CRVO events during treatment.

Of the seven CRAO-AF cases with high pre-treatment homocysteine (Table 2), five were treated with folic acidvitamin B6-vitamin B12 for a median of 6 months (interquartile range 5-8 months). Homocysteine levels normalized in all five, falling from $15.8 \pm 1.1$ to $9.3 \pm 3.1 \mu \mathrm{mol} / \mathrm{L}, P=0.06$. In these five cases, there were no new CRAO-AF events during treatment. There were no adverse side effects associated with the folic acid-vitamin B6-vitamin B12 treatment.

\section{CRVO, CRAO, and AF after starting estrogen -} estrogen agonist therapy in six of the women subsequently shown to have underlying inherited or acquired thrombophilia

Of 96 women in the cohort, eleven (11\%) sustained an RVO while using estrogens or estrogen agonists, and six were found to have a previously undiagnosed thrombophilia (Table 3). Five of the six were 55 years old or older (Table 3 ). RVO was the first clinical thrombotic event in all six women (Table 3).

Of 77 women with CRVO, four (5\%)-aged 37 to 53 years-presented after taking estrogen-progestin oral contraceptives $(n=2)$, estrogen-testosterone $(n=1)$, or tamoxifen $(n=1)$ (Table 3$)$. Of these four, two were subsequently shown to have high homocysteine, two had inherited high factor XI, and one had the lupus anticoagulant (Table 3). CRVO occurred after as little as 11 months to as long as 5 years after starting estrogen-progestins, estrogen-testosterone, or tamoxifen for all four women (Table 3 ).

Of eight women with CRAO, one (13\%) presented after taking conjugated estrogen tablets for 8 years, and was subsequently found to have high anticardiolipin antibody IgG (Table 3).

Table 2 Comparisons of coagulation measures between 32 patients - 15 with CRAO, 17 with AF, and I04 healthy, normal controls

\begin{tabular}{|c|c|c|c|c|}
\hline Coagulation measures (normal range) & Abnormal in CRAO & Abnormal in controls & $\mathbf{P}$ & OR, $95 \% \mathrm{CI}$ \\
\hline Homocysteine $(\leq 13.5 \mu \mathrm{mol} / \mathrm{L})$ & $22 \%(7 / 32)$ & $2 \%(2 / 102)$ & Fisher's $P=0.0006$ & $|4.0,2.7-7| .6$ \\
\hline Lupus anticoagulant & $28 \%(7 / 25)$ & $9 \%(7 / 81)$ & Fisher's $P=0.02$ & $4.1,1.3-13.2$ \\
\hline Factor $V$ Leiden mutation & $6 \%$ CT $(2 / 32)$ & $2 \%$ CT $(2 / 104)$ & Fisher's $P=0.2$ & \\
\hline Resistance to activated protein C (dated cutpoint) & $7 \%(2 / 30)$ & $5 \%(5 / 92)$ & Fisher's $P=1.0$ & \\
\hline Prothrombin gene mutation & $6 \%$ CT $(2 / 32)$ & $3 \%$ CT $(3 / 105)$ & Fisher's $P=0.3$ & \\
\hline \multirow[t]{2}{*}{ Plasminogen activator inhibitor gene mutation } & $29 \% 4 G 4 G(9 / 3 I)$ & $26 \% 4 G 4 G(26 / 100)$ & Mantel-Haenszel & \\
\hline & $52 \%$ 4G5G (I6/3I) & $43 \% 4 G 5 G(43 / 100)$ & $\chi^{2}=0.92, P=0.3$ & \\
\hline \multirow[t]{2}{*}{ MTHFR C677T mutation } & $42 \%$ CC $(13 / 3 \mid)$ & $31 \%$ CC $(31 / 101)$ & Mantel-Haenszel & \\
\hline & $19 \%$ CT $(6 / 31)$ & $14 \%$ CT $(14 / 101)$ & $\chi^{2}=2.26, P=0.1$ & \\
\hline Antigenic protein $C(\geq 73 \%)$ & $13 \%(4 / 32)$ & $7 \%(6 / 92)$ & Fisher's $P=0.3$ & \\
\hline Antigenic protein S ( $\geq 63 \%)$ & $0 \%(0 / 32)$ & $4 \%(4 / 92)$ & Fisher's $P=0.6$ & \\
\hline Antigenic-free protein $S(\geq 66 \%)$ & $3 \%(1 / 30)$ & $2 \%(2 / 92)$ & Fisher's $P=1.0$ & \\
\hline Antithrombin III ( $\geq 80)$ & $10 \%(3 / 31)$ & $2 \%(2 / 92)$ & Fisher's $P=0.1$ & \\
\hline Anticardiolipin antibody $\lg G(<22$ GPL) & $9 \%(3 / 32)$ & $7 \%(7 / 104)$ & Fisher's $P=0.7$ & \\
\hline Anticardiolipin antibody IgM (<10 MPL) & $6 \%(2 / 32)$ & $2 \%(2 / 104)$ & Fisher's $P=0.2$ & \\
\hline Plasminogen activator inhibitor $(\leq 21.1 \mathrm{U} / \mathrm{mL})$ & $13 \%(4 / 30)$ & $10 \%(10 / 97)$ & Fisher's $P=0.7$ & \\
\hline $\mathrm{Lp}(\mathrm{a})(<35 \mathrm{mg} / \mathrm{dL})$ & $13 \%(4 / 3 \mid)$ & $20 \%(20 / 102)$ & $\chi^{2}=0.72, P=0.4$ & \\
\hline Factor VIII $(<150 \%)$ & $19 \%(6 / 32)$ & $7 \%(7 / 98)$ & Fisher's $P=0.1$ & \\
\hline Factor $\mathrm{XI}(<\mathrm{I} 50 \%)$ & $9 \%(3 / 32)$ & $2 \%(2 / 96)$ & Fisher's $P=0.1$ & \\
\hline
\end{tabular}

Abbreviations: $\mathrm{Cl}$, confidence interval; C, mutant allele; OR, odds ratio; T, wild-type normal allele; Lp(a), lipoprotein a; CRVO, central retinal vein occlusion; Ig, immunoglobulin. 
Table 3 Central retinal vein, central retinal artery occlusion, and amaurosis fugax after the use of exogenous estrogens or estrogen agonists in six women subsequently shown to have inherited or acquired thrombophilia

\begin{tabular}{|c|c|c|c|c|}
\hline Case \# & Age & Coagulation disorders & $\begin{array}{l}\text { Exogenous estrogen } \\
\text { or estrogen agonist }\end{array}$ & $\begin{array}{l}\text { Duration of estrogen or estrogen agonist } \\
\text { use prior to ocular thrombotic event }\end{array}$ \\
\hline \multicolumn{5}{|c|}{ Of 77 women with central retinal vein occlusion } \\
\hline 1 & 51 & High factor $X I$ & Nolvadex & 5 years \\
\hline 2 & 53 & High serum homocysteine & Estrogen-testosterone & II months \\
\hline 3 & 42 & High serum homocysteine & Estrogen-progestin oral contraceptive & 2 years \\
\hline 4 & 37 & Lupus anticoagulant, high factor $\mathrm{XI}$ & Estrogen-progestin oral contraceptive & II months \\
\hline \multicolumn{5}{|c|}{ Of eight women with central retinal artery occlusion } \\
\hline 5 & 55 & High anticardiolipin antibody lgG & Conjugated estrogen tablets & 8 years \\
\hline \multicolumn{5}{|c|}{ Of eleven women with amaurosis fugax } \\
\hline 6 & 79 & Protein $\mathrm{S}$ deficiency & Conjugated estrogen tablets & 2 years \\
\hline
\end{tabular}

Abbreviation: Ig, immunoglobulin.

Of eleven women with $\mathrm{AF}$, one (9\%) presented after taking conjugated estrogen tablets for 2 years, and was subsequently found to have inherited protein $\mathrm{S}$ deficiency (Table 3).

\section{Case-control differences in risk factors for atherosclerosis}

Based on age-sex-specific lipid distributions from healthy general populations from the Lipid Research Clinics Prevalence Study, ${ }^{36}$ the mean percentiles in 132 CRVO cases were $34 \%$ for total cholesterol (TC), $52 \%$ for triglycerides (TGs), 49\% for high-density lipoprotein cholesterol (HDLC), and $29 \%$ for low-density lipoprotein cholesterol (LDLC). In 32 CRAO-AF cases, the mean percentiles were $32 \%$ for TC, $47 \%$ for TG, $48 \%$ for HDLC, and $29 \%$ for LDLC. Thus, for TG and HDLC, CRVO and CRAO-AF cases were in the middle of the normal distribution, and both had TC and LDLC percentiles in the lower third of the distribution.

Of the 132 CRVO cases, $7 \%$ had type 2 diabetes, $43 \%$ had hypertension, and $17 \%$ smoked, compared to US population estimates ${ }^{37,38}$ of $8 \%, 24 \%$, and $20 \%$, respectively, with an excess of hypertension in CRVO cases. Of the 32 cases with CRAO-AF, $16 \%$ had type 2 diabetes, $34 \%$ had hypertension, and $16 \%$ smoked, with an excess of type 2 diabetes and hypertension in CRAO-AF cases.

\section{Discussion}

Our report, as well as earlier studies, ${ }^{16,27-29}$ has established thrombophilia as a common pathoetiologic cause of RVO. In this study, in agreement with previously published studies, ${ }^{27,34,47-51}$ we found significant enrichment in hyperhomocysteinemia in our 132 CVRO cases $(15 \%$ versus $2 \%$ in controls; $P=0.0008)$. Hansen et $\mathrm{al}^{34}$ reported a high prevalence of hyperhomocysteinemia in retinal venous thrombosis, even superseding the prevalence of venous thromboembolism in other compartments.
Sofi et a ${ }^{52}$ reported that low vitamin B6 levels, low folic acid levels, and elevated homocysteine levels were each independently associated with CRVO, offering therapeutic targets for normalization of serum vitamin B6 and B12 and folate levels to lower homocysteine, as was successfully done in our study.

In the current study of CRVO cases, and congruent with other reports, when compared to normal controls, we found that CRVO cases had high anticardiolipin antibodies, ${ }^{53}$ inherited low protein $\mathrm{S},{ }^{27}$ and inherited high factor VIII. ${ }^{27,54}$

Congruent with previously published studies ${ }^{1,2,55}$ we found that homocysteinemia was much more common in cases with CRAO-AF than in controls $(22 \%$ versus $2 \%$; $P=0.0006)$. In agreement with previous reports, cases with CRAO-AF were more likely than normal controls to have the lupus anticoagulant. ${ }^{56}$

A novel finding of the current study was that treatment with folic acid-B6-B12 normalized serum homocysteine in $81 \%$ of CRVO cases and in $100 \%$ of CRAO-AF cases with pre-treatment homocysteinemia. Normalizing high serum homocysteine levels in cases with CRVO and CRAO-AF may reduce the risk of subsequent ocular venous or arterial thrombosis, ${ }^{5,57}$ as well as reduce the risk of thrombi in other venous and arterial beds, especially the brain, since hyperhomocysteinemia is associated with both venous and arterial thrombosis. ${ }^{51,52,58-61}$ However, in a placebo-controlled study, folic acid-vitamin B6-vitamin B12 therapy, which lowered homocysteine, did not reduce the risk for symptomatic venous thromboembolism. ${ }^{62}$ An optimal study of normalizing high homocysteine with folic acid-vitamin B6-vitamin B12 in patients with CRVO and CRAO-AF in an attempt to prevent recurrent RVO events or other thrombotic events would be blinded and placebo-controlled, and would run for 5 years. ${ }^{62}$

In addition to thrombophilic risk factors for CRVO and CRAO-AF, atherosclerotic risk factors and cigarette smoking 
have been implicated as causative factors., ${ }^{2,63}$ In the current study, hypertension - but not hyperlipidemia - was common in CRVO and CRAO-AF cases, and type 2 diabetes was common in CRAO-AF cases.

Previous studies $^{64}$ and case reports ${ }^{10-13,18,19}$ have emphasized that RVO can be triggered by estrogens, estrogenprogestins, clomiphene citrate, ${ }^{8}$ or SERMS, but these studies did not explore for underlying and/or previously undiagnosed inherited and/or acquired thrombophilia or hypofibrinolysis. A novel finding of the current study was that, of 96 women with RVO, six (6\%) first sustained RVO 3 years (on average) after beginning to take estrogens or estrogen agonists and were subsequently discovered to have inherited and/or acquired thrombophilia. Our report casts light on the pathophysiologic interaction ${ }^{65}$ leading to RVO between pharmacologic thrombophilia conferred by exogenous estrogens or estrogen agonists and inherited or acquired thrombophilia-hypofibrinolysis. ${ }^{66}$ When CRVO or CRAO-AF occurs in women receiving estrogens or estrogen agonists, particularly at 55 years old and older, we suggest evaluation for underlying inherited and acquired thrombophilia. Thrombophilia contributes to the risk of thrombosis in women using estrogen-progestin oral contraceptives or hormone replacement therapy. ${ }^{65}$ In postmenopausal women taking estrogen-progestin hormone replacement therapy, the presence of inherited thrombophilia (factor V Leiden, high factor VIII) increases the risk of deep venous thrombosis 17-fold compared to women without inherited thrombophilia who do not use hormone replacement therapy. ${ }^{66}$

\section{Conclusion}

Treatable thrombophilia, particularly hyperhomocysteinemia, is more common in RVO cases than in normal controls. RVO occurring after estrogens or estrogen agonist use in women should stimulate an assessment for any underlying thrombophilia.

\section{Acknowledgments/disclosure}

The authors declare no conflicts of interest in this work. This research was supported in part by the Lipoprotein and Metabolic Research Funds of the Jewish Hospital of Cincinnati, and by the Medical Research Council of the Jewish Hospital of Cincinnati.

\section{References}

1. Sottilotta G, Oriana V, Latella C, et al. Role of hyperhomocystinemia in retinal vascular occlusive disease. Clin Appl Thromb Hemost. 2007;13(1): 104-107.

2. Marcucci R, Sodi A, Giambene B, et al. Cardiovascular and thrombophilic risk factors in patients with retinal artery occlusion. Blood Coagul Fibrinolysis. 2007;18(4):321-326.
3. Sottilotta G, Siboni SM, Latella C, et al. Hyperhomocysteinemia and C677T MTHFR genotype in patients with retinal vein thrombosis. Clin Appl Thromb Hemost. 2010;16(5):549-553.

4. Kuo JZ, Lai CC, Ong FS, et al. Central retinal vein occlusion in a young Chinese population: risk factors and associated morbidity and mortality. Retina. 2010;30(3):479-484.

5. Marcucci R, Sofi F, Grifoni E, Sodi A, Prisco D. Retinal vein occlusions: a review for the internist. Intern Emerg Med. 2011;6(4):307-314.

6. Glueck CJ, Wang P, Fontaine RN, Sieve-Smith L, Lang JE. Estrogen replacement therapy, thrombophilia, and atherothrombosis. Metabolism. 2002;51(6):724-732.

7. Petitti DB. Clinical practice. Combination estrogen-progestin oral contraceptives. N Engl J Med. 2003;349(15):1443-1450.

8. Viola MI, Meyer D, Kruger T. Association between clomiphene citrate and visual disturbances with special emphasis on central retinal vein occlusion: a review. Gynecol Obstet Invest. 2011;71(2):73-76.

9. Gorin MB, Costantino JP, Kulacoglu DN, et al. Is tamoxifen a risk factor for retinal vaso-occlusive disease? Retina. 2005;25(4): 523-526.

10. Murray DC, Christopoulou D, Hero M. Combined central retinal vein occlusion and cilioretinal artery occlusion in a patient on hormone replacement therapy. Br J Ophthalmol. 2000;84(5):549-550.

11. Mayer H. A contribution about serious ophthalmic complications with oral contraceptives. Klin Monbl Augenheilkd. 1979;175(5):677-680. German.

12. Jaworek K. Case of central retinal vein thrombosis in a young woman treated with progesterone. Klin Oczna. 1976;46(1):75-78. Polish.

13. Leong KC, Tan PL. Central retinal vein thrombosis in a woman on contraceptive pills. Singapore Med J. 1974;15(2):156-157.

14. Güven D, Sayinalp N, Kalayci D, Dündar S, Hasiripi H. Risk factors in central retinal vein occlusion and activated protein $\mathrm{C}$ resistance. Eur J Ophthalmol. 1999;9(1):43-48.

15. Glueck CJ, Goldenberg N, Bell H, Golnik K, Wang P. Amaurosis fugax: associations with heritable thrombophilia. Clin Appl Thromb Hemost. 2005;11(3):235-241.

16. Glueck CJ, Golnik K, Ping W. Amaurosis fugax caused by heritable thrombophilia-hypofibrinolysis in cases without carotid atherosclerosis: thromboprophylaxis prevents subsequent transient monocular partial blindness. Clin Appl Thromb Hemost. 2007;13(2):124-129.

17. Roşca T. Methods of prevention of ischemic cerebral damages in patients with antiphospholipid antibodies. Oftalmologia. 2008;52(2): 72-76. Romanian.

18. Vastag O, Tornóczky J. Arterial occlusion in the ocular fundus induced by oral contraceptives. Orv Hetil. 1984;125(51):3121-3125. Hungarian.

19. Paufique L, Lequin M. Thrombosis of the retinal artery and oral contraceptives. Bull Soc Ophtalmol Fr. 1968;68(4):512-515. French.

20. Blade J, Darleguy P, Chanteau Y. Early thrombosis of the central retinal artery and oral contraceptives. Bull Soc Ophtalmol Fr. 1971;71(1):48-49. French.

21. Jampol LM, Isenberg SJ, Goldberg MF. Occlusive retinal arteriolitis with neovascularization. Am J Ophthalmol. 1976;81(5):583-589.

22. Gombos GM, Moreno DH, Bedrossian PB. Retinal vascular occlussion induced by oral contraceptives. Ann Ophthalmol. 1975; $7(2): 215-217$.

23. Friedman S, Golan A, Shoenfeld A, Goldman J. Acute ophthalmologic complications during the use of oral contraceptives. Contraception. 1974;10(6):685-692.

24. Glueck CJ, Bell H, Vadlamani L, et al. Heritable thrombophilia and hypofibrinolysis. Possible causes of retinal vein occlusion. Arch Ophthalmol. 1999;117(1):43-49.

25. Glueck CJ, Fontaine RN, Wang P. Interaction of heritable and estrogen-induced thrombophilia: possible etiologies for ischemic optic neuropathy and ischemic stroke. Thromb Haemost. 2001;85(2): 256-259.

26. Glueck CJ, Hutchins RK, Khan A, Bains PS, Khan N, Wang P. Successful anticoagulation for bilateral central retinal vein occlusion. Clin Chim Acta. 2011;412(11-12):1165-1166. 
27. Glueck CJ, Ping W, Hutchins R, Petersen MR, Golnik K. Ocular vascular thrombotic events: central retinal vein and central retinal artery occlusions. Clin Appl Thromb Hemost. 2008;14(3):286-294.

28. Glueck CJ, Wang P, Bell H, Rangaraj V, Goldenberg N. Nonarteritic anterior ischemic optic neuropathy: associations with homozygosity for the C677T methylenetetrahydrofolate reductase mutation. J Lab Clin Med. 2004;143(3):184-192.

29. Glueck CJ, Wang P, Bell H, Rangaraj V, Goldenberg N. Associations of thrombophilia, hypofibrinolysis, and retinal vein occlusion. Clin Appl Thromb Hemost. 2005;11(4):375-389.

30. Cheung N, Klein R, Wang JJ, et al. Traditional and novel cardiovascular risk factors for retinal vein occlusion: the multiethnic study of atherosclerosis. Invest Ophthalmol Vis Sci. 2008;49(10): 4297-4302.

31. Greiner K, Hafner G, Dick B, Peetz D, Prellwitz W, Pfeiffer N. Retinal vascular occlusion and deficiencies in the protein $\mathrm{C}$ pathway. Am J Ophthalmol. 1999;128(1):69-74.

32. Larsson J. Central retinal artery occlusion in a patient homozygous for factor V Leiden. Am J Ophthalmol. 2000;129(6):816-817.

33. Larsson J, Hillarp A, Olafsdottir E, Bauer B. Activated protein C resistance and anticoagulant proteins in young adults with central retinal vein occlusion. Acta Ophthalmol Scand. 1999;77(6):634-637.

34. Hansen L, Kristensen HL, Bek T, Ingerslev J. Markers of thrombophilia in retinal vein thrombosis. Acta Ophthalmol Scand. 2000;78(5): 523-526.

35. Scott JA, Arnold JJ, Currie JM, et al. No excess of factor V:Q506 genotype but high prevalence of anticardiolipin antibodies without antiendothelial cell antibodies in retinal vein occlusion in young patients. Ophthalmologica. 2001;215(3):217-221.

36. Lipid Research Clinics. Population Studies Data Book. Vol 1. The Prevalence Study. NIH publication no 80-1527. Bethesda, MD; National Institutes of Health; 1980.

37. National Center for Health Statistics. Plan and operation of the third National Health and Nutrition Survey, 1988-1994. Series 1: programs and collection procedures. Vital Health Stat 1. 1994;32:1-407.

38. Harris MI, Flegal KM, Cowie CC, et al. Prevalence of diabetes, impaired fasting glucose, and impaired glucose tolerance in US adults. The Third National Health and Nutrition Examination Survey, 1988-1994. Diabetes Care. 1998;21(4):518-524.

39. Balasa VV, Gruppo RA, Glueck CJ, et al. The relationship of mutations in the MTHFR, prothrombin, and PAI-1 genes to plasma levels of homocysteine, prothrombin, and PAI-1 in children and adults. Thromb Haemost. 1999;81(5):739-744.

40. Glueck CJ, Wang P, Bornovali S, Goldenberg N, Sieve L. Polycystic ovary syndrome, the G1691A factor V Leiden mutation, and plasminogen activator inhibitor activity: associations with recurrent pregnancy loss. Metabolism. 2003;52(12):1627-1632.

41. Glueck CJ, Iyengar S, Goldenberg N, Smith LS, Wang P. Idiopathic intracranial hypertension: associations with coagulation disorders and polycystic-ovary syndrome. J Lab Clin Med. 2003;142(1): $35-45$.

42. Glueck CJ, Wang P, Goldenberg N, Sieve L. Pregnancy loss, polycystic ovary syndrome, thrombophilia, hypofibrinolysis, enoxaparin, metformin. Clin Appl Thromb Hemost. 2004;10(4):323-334.

43. Glueck CJ, Pranikoff J, Aregawi D, et al. The factor V Leiden mutation, high factor VIII, and high plasminogen activator inhibitor activity: etiologies for sporadic miscarriage. Metabolism. 2005;54(10): 1345-1349.

44. Glueck CJ, Aregawi D, Goldenberg N, Golnik KC, Sieve L, Wang P. Idiopathic intracranial hypertension, polycystic-ovary syndrome, and thrombophilia. J Lab Clin Med. 2005;145(2):72-82.

45. Glueck CJ, Glueck HI, Tracy T, Speirs J, McCray C, Stroop D. Relationships between lipoprotein(a), lipids, apolipoproteins, basal and stimulated fibrinolytic regulators, and D-dimer. Metabolism. 1993;42(2):236-246.

46. Glueck CJ, Freiberg RA, Fontaine RN, Tracy T, Wang P. Hypofibrinolysis, thrombophilia, osteonecrosis. Clin Orthop Relat Res. 2001;386: 19-33.
47. Abu El-Asrar AM, Abdel Gader AG, Al-Amro SA, Al-Attas OS. Hyperhomocysteinemia and retinal vascular occlusive disease. Eur $J$ Ophthalmol. 2002;12(6):495-500.

48. Weger M, Stanger O, Deutschmann H, et al. Hyperhomocyst(e)inemia and MTHFR C677T genotypes in patients with central retinal vein occlusion. Graefes Arch Clin Exp Ophthalmol. 2002;240(4): 286-290.

49. Ferrazzi P, Di Micco P, Quaglia I, et al. Homocysteine, MTHFR C677T gene polymorphism, folic acid and vitamin B 12 in patients with retinal vein occlusion. Thromb J. 2005;3:13.

50. Lattanzio R, Sampietro F, Ramoni A, Fattorini A, Brancato R, D’Angelo A. Moderate hyperhomocysteinemia and early-onset central retinal vein occlusion. Retina. 2006;26(1):65-70.

51. Sodi A, Giambene B, Marcucci R, et al. Atherosclerotic and thrombophilic risk factors in patients with recurrent central retinal vein occlusion. Eur J Ophthalmol. 2008;18(2):233-238.

52. Sofi F, Marcucci R, Bolli P, et al. Low vitamin B6 and folic acid levels are associated with retinal vein occlusion independently of homocysteine levels. Atherosclerosis. 2008;198(1):223-227.

53. Bick RL. Antiphospholipid thrombosis syndromes. Hematol Oncol Clin North Am. 2003;17(1):115-147.

54. Faude F, Faude S, Siegemund A, Wiedemann P. Factor VIII activity in patients with central retinal vein occlusion in comparison to patients with a history of pelvic and lower limb venous thrombosis and a healthy control group [in German]. Klin Monbl Augenheilkd. 2004;221(10):862-866.

55. Cahill M, Karabatzaki M, Meleady R, et al. Raised plasma homocysteine as a risk factor for retinal vascular occlusive disease. Br J Ophthalmol. 2000;84(2):154-157.

56. Coroi M, Bontas E, Defranceschi M, Bartos D, Dorobantu M. Ocular manifestations of antiphospholipid (Hughes)' syndrome - minor features? Oftalmologia. 2007;51(3):16-22.

57. Cacciapuoti F. Some considerations about the hypercoagulable states and their treatments. Blood Coagul Fibrinolysis. 2011;22(3) $155-159$.

58. den Heijer M, Brouwer IA, Bos GM, et al. Vitamin supplementation reduces blood homocysteine levels: a controlled trial in patients with venous thrombosis and healthy volunteers. Arterioscler Thromb Vasc Biol. 1998;18(3):356-361

59. Green TJ, Skeaff CM, McMahon JA, et al. Homocysteine-lowering vitamins do not lower plasma S-adenosylhomocysteine in older people with elevated homocysteine concentrations. Br J Nutr. 2010;103(11):1629-1634.

60. Hoțoleanu C, Porojan-Iuga M, Rusu ML, Andercou A. Hyperhomocysteinemia: clinical and therapeutical involvement in venous thrombosis. Rom J Intern Med. 2007;45(2):159-164.

61. Di Minno MN, Tremoli E, Coppola A, Lupoli R, Di Minno G. Homocysteine and arterial thrombosis: challenge and opportunity. Thromb Haemost. 2010;103(5):942-961.

62. Ray JG, Kearon C, Yi Q, et al. Homocysteine-lowering therapy and risk for venous thromboembolism: a randomized trial. Ann Intern Med. 2007;146(11):761-767.

63. Sodi A, Giambene B, Marcucci R, et al. Atherosclerotic and thrombophilic risk factors in patients with ischemic central retinal vein occlusion. Retina. 2011;31(4):724-729.

64. Salomon O, Huna-Baron R, Kurtz S, et al. Analysis of prothrombotic and vascular risk factors in patients with nonarteritic anterior ischemic optic neuropathy. Ophthalmology. 1999;106(4):739-742.

65. DeSancho MT, Dorff T, Rand JH. Thrombophilia and the risk of thromboembolic events in women on oral contraceptives and hormone replacement therapy. Blood Coagul Fibrinolysis. 2010;21(6):534-538.

66. Douketis JD, Julian JA, Crowther MA, et al. The effect of prothrombotic blood abnormalities on risk of deep vein thrombosis in users of hormone replacement therapy: a prospective case-control study. Clin Appl Thromb Hemost. 2011;17(6):E106-E113. 


\section{Publish your work in this journal}

Clinical Ophthalmology is an international, peer-reviewed journal covering all subspecialties within ophthalmology. Key topics include: Optometry; Visual science; Pharmacology and drug therapy in eye diseases; Basic Sciences; Primary and Secondary eye care; Patient Safety and Quality of Care Improvements. This journal is indexed on

Submit your manuscript here: http://www.dovepress.com/clinical-ophthalmology-journal
PubMed Central and CAS, and is the official journal of The Society of Clinical Ophthalmology (SCO). The manuscript management system is completely online and includes a very quick and fair peer-review system, which is all easy to use. Visit http://www.dovepress.com/ testimonials.php to read real quotes from published authors. 